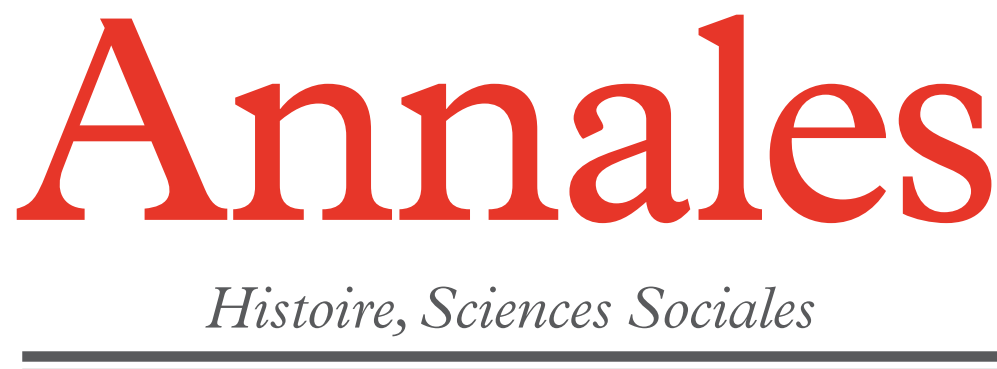

\title{
The Anthropocene
}

Grégory Quenet

Pierre Charbonnier

Fan Zalasiewicz · Colin Waters · Mark Williams

Bruno Karsenti

\section{The History of Commerce (Sixteenth to Nineteenth Century)}

\author{
Nadia Matringe \\ Arnaud Bartolomei · Matthieu de Oliveira · Fabien Eloire \\ Claire Lemercier · Nadège Sougy \\ $72^{\text {nd }}$ Year $-\mathrm{n}^{\circ} 2$ \\ April-June 2017 \\ ÉDITIONS DE L'ÉCOLE \\ DES HAUTES ÉTUDES \\ EN SCIENCES SOCIALES \\ CAMBRIDGE \\ UNIVERSITY PRESS
}




\section{Annales}

Histoire, Sciences Sociales

\section{$72^{\text {nd }}$ Year \\ no. 2 April-June 2017}

\section{The Anthropocene}

Grégory QueneT

The Anthropocene and the Time of Historians

Pierre Charbonnier

A Genealogy of the Anthropocene

The End of Risk and Limits

Jan Zalasiewicz, Colin Waters, and Mark Williams

City-Strata of the Anthropocene

Bruno Karsenti

Political Ecology and Modern Politics

\section{The History of Commerce (Sixteenth to Nineteenth Century)}

Nadia Matringe

The Fair Deposit

Credit Reallocation and Trade Finance in the Early Modern Period

Arnaud Bartolomei, Matthieu de Oliveira, Fabien Eloire,

Claire Lemercier, and Nadège SougY

The Embeddedness of Inter-Merchant Relations in France (1750-1850)

A Revolution in the World of Commerce?

Abstracts 
This English edition of Annales HSS 72, no.2 (2017) was published January-March 2018.

Editorial information online: http://annales.ehess.fr

Annales Editorial Office

EHESS, 105 boulevard Raspail 75006 Paris (France)

Tel.: +33 (0)153105377

E-mail: annales@ehess.fr

The French edition of the Annales is available in open access on the following platforms:

- Cairn (www.cairn.info/revue-annales.htm), from 2001, with a four-year delay

- Gallica (www.gallica.bnf.fr), from 1929 to 1938

- Persée (www.persee.fr/collection/ahess), 1929-1932, 1939-1941, and 1943-2002

and by subscription through:

- Cambridge Core (www.cambridge.org/annales), from 1929

- Jstor (www.jstor.org/journal/annahistscisoc), from 1929, with a five-year delay

The English edition of the Annales is available on the following platforms:

- Cairn international (www.cairn-int.info/journal-annales.htm), from 2012 to 2016

- Cambridge Core (www.cambridge.org/annales-in-English), from 2012 to current

- Revues.org (www.revues.org), from 2012 to 2016

Since 2017, the Annales has been published in print and online by Éditions EHESS in partnership with Cambridge University Press. Subscriptions can be purchased through subscription agents or directly through Cambridge University Press:

Cambridge University Press (Journals)

University Printing House

Shaftesbury Road

Cambridge, CB2 8BS (UK)

journals@cambridge.org

Subscriptions begin with the first issue of the year. Prices and a subscription form can be found at the end of each issue and at www.cambridge.org/annales/subscribe-en.

Sale by issue (French edition only, France, Belgium, and Switzerland): $25 €$

Bookstore orders

CDE (Centre de diffusion de l'édition), 17 rue de Tournon 75006 Paris (France)

Distribution

SODIS, 128 avenue du Maréchal-de-Lattre-de-Tassigny 77400 Lagny-sur-Marne (France)

Sale by issue (international): contact Cambridge University Press

Layout: Michel Rohmer

(C) École des hautes études en sciences sociales, Paris, 2020

ISSN: 2398-5682 (English edition in print), 2268-3763 (English edition online) 


\section{Annales}

Histoire, Sciences Sociales

Founders: Marc Bloch and Lucien Febvre

Former Editor: Fernand Braudel

Quarterly review published since 1929, edited by the École des hautes études en sciences sociales with the support of the Florence Gould Foundation and the American University of Paris

\section{Advisory Board}

Mary Beard, Jane Burbank, Sandro Carocci, Jocelyne Dakhlia, Lorraine Daston, Marc Ferro, François Hartog, António Manuel Hespanha, Christian Lamouroux, Emmanuel Le Roy Ladurie, Alf Lüdtke, André Orléan, Jacques Poloni-Simard, Jacques Revel, Pierre-François Souyri, Sanjay Subrahmanyam, Laurent Thévenot, Lucette Valensi

\section{Editor}

Vincent Azoulay

\section{Editorial Board}

Étienne Anheim, Romain Bertrand, André Burguière, Guillaume Calafat, Vanessa Caru, Jean-Yves Grenier, Catherine Kikuchi, Camille Lefebvre, Antoine Lilti, Antonella Romano, Anne Simonin, Michael Werner

\section{Associate Editors for the English Edition}

Nicolas Barreyre, Stephen W. Sawyer

\section{Assistant Editors}

Aurianne Cox, Livia Foraison, Séverine Guiton, Chloe Morgan 